\title{
Relations between India and Nepal in covid-19 situation
}

\begin{abstract}
India - Nepal relations are-deep, wide- ranging and unique. History, geography and economy make Nepal and India natural partner, sharing interest in each other's freedom, integrity, dignity, security and progress. The kind of close relations India has shared with Nepal historical has not been shared with any other country. The two countries not only share an open border and unhindered movement of people but they also have close bonds through marriage and familial ties popularly known as "Roti-Beti Ka Rishta" (Relation of food and marriage). They can also reside and work in each other's country. But these relations have begun to sour over the past few days and years. In recent time a border dispute is growing between both the countries. So, what is the border dispute? Why did the start? And who is right in this scenario? This paper tries to emphasize all of these issues.
\end{abstract}

Volume 5 Issue 5 - 2020

\author{
Saurabh Dalal \\ Assistant Teacher in Political Science, Bhotepatty H.B.L. High \\ School (H.S), India
}

\begin{abstract}
Correspondence: Saurabh Dalal,Assistant Teacher in Political Science, Bhotepatty H.B.L. High School (H.S), Former Teacher, Sree Ramakrishna Sisu Thirtha High School, Dankuni,West Bengal, Email saurabhdalal70@gmail.com
\end{abstract}

Received: September 20, 2020 | Published: October 20, 2020

Keywords: treaty of sugauli, disputed area, pilgrimage, kalapani, limpiyadhura, kingdom of Nepal

\section{Introduction}

Nepal is an important state to India. They have been sharing border with five Indian states Uttarakhand, Uttar Pradesh, West Bengal, Sikkim and Bihar, hence an important point of culture and economic exchange. Nepal is right in the middle of India's Himalayan frontiers and along with Bhutan it acts as northern borderland flanks and acts as buffer States against any possible aggression from China. Rivers have been originating in Nepal feat the perennial river systems of India in terms of ecology and hydropower potential. So many Hindu and Buddhist religious sites are in Nepal making it an important pilgrim site for large number of Indians. But recently the prime minister of Nepal claimed that India is responsible for the spread of coronavirus in Nepal. Furthermore the prime minister of Nepal has accused India of occupying some areas of Nepal. Actually this controversy surfaced within the Indian media when Nepal came out with its new map a few days ago. They came out with a new map of their country and within it; they included an area which did not belong to them in the past. This areas which are under India's control today. If you look at their new map, this area is a triangular shaped disputed area in the north-western tip of Nepal. This area is the eastern most tip of Uttarakhand. This entails an area of around 300 square kilometres and the north most village/place Limpiyadhura. The south eastern part of it is Lipulekh pass; Gunji lies in the south-west and Kalapani in the south. So this area has been defined on the basis of these three places Limpiyadhura, Lipulekh and Kalapani. Nepal believes that this area rightfully belongs to them whereas India believes it is India's. Before addressing the question of who is right and what the history of this land is. First, this controversy broke out due to two events which was happened it around few months ago. The first event happened on November 2019. Indian government released a new map of India, in which the region of Kalapani was claimed to be under India, which triggered the Nepal government. ${ }^{1-5}$

The second event happened on 8 May, 2020, when the Indian defence minister inaugurated a new road. This road was around 80 kilometres along the India Nepal border to this disputed area uptill Lipulekh. The purpose of this road was to aid the people on the Kailash Mansarovar Yatra as per claims. Because above this disputed areas lies Tibet where the Kailash Mansarovar is situated. Before the construction of this route, the yatris had to go to the Kailash Mansarovar via Sikkim. It was a trek of five days. After the construction of this road, they will reach China's border in a car, which will be followed by a mere 2 day walk (Figure 1). After the inauguration of this road, the Nepal government was upset and they believed that if India had to construct this road, they should have consulted Nepal first and worked out an agreement before doing this. In response to this, the external affairs ministry of India said that this area comes completely under the territory of India and therefore they did not hold a consultation with Nepal. This was not required because they had constructed a road within their own territory. But situations began to go from bad to worse when this was protested in Nepal. The army chief on $15^{\text {th }}$ May said that the protests in Nepal were influenced by China. This further upset the people in Nepal and then the Nepal government released this new map on 20 may 2020 which brought the entire dispute to light. So the question is who truly own this disputed region? And which country does it rightfully belong to? (Figure 2). ${ }^{6-10}$ 


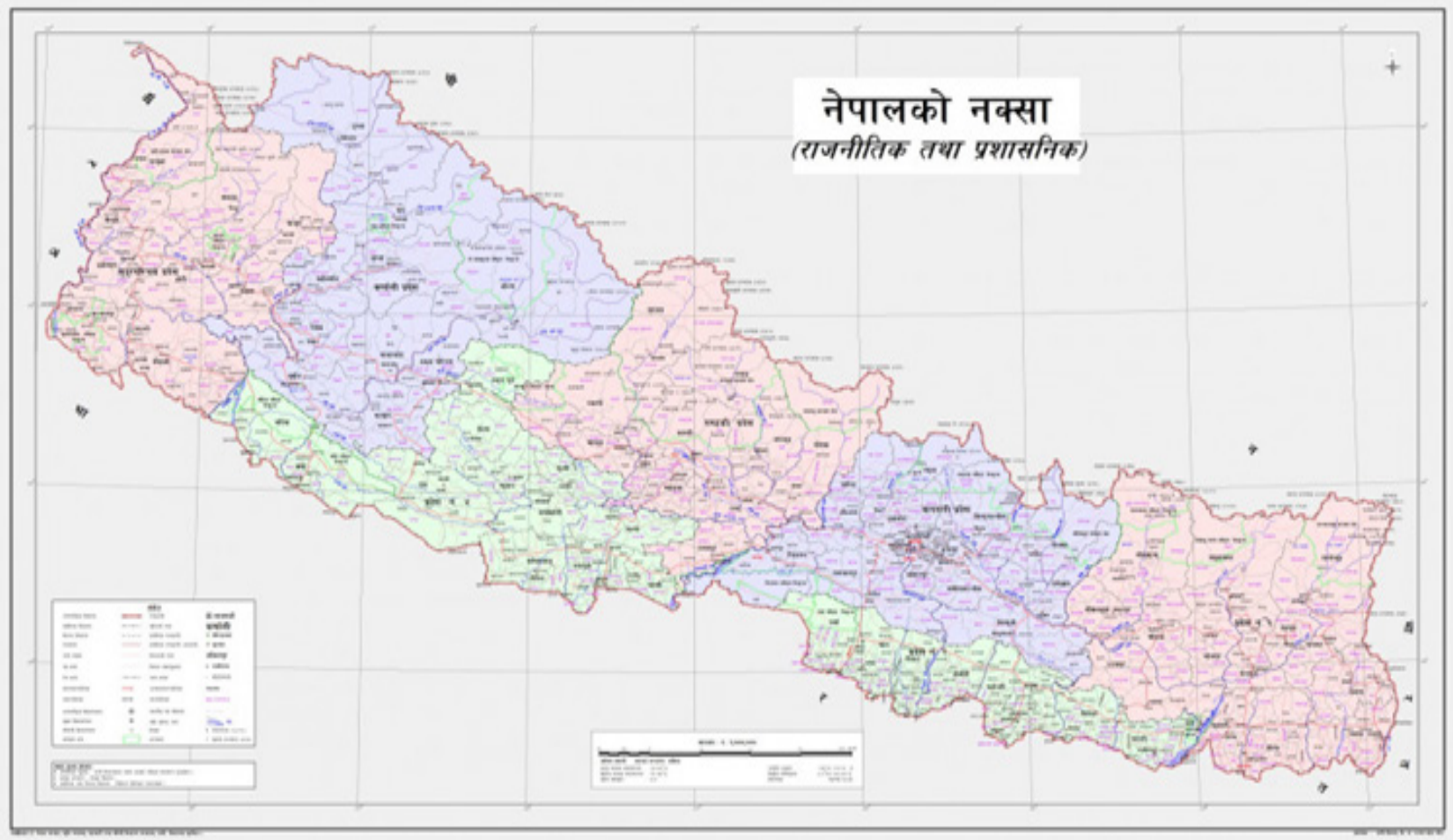

Figure I New political map of Nepal.

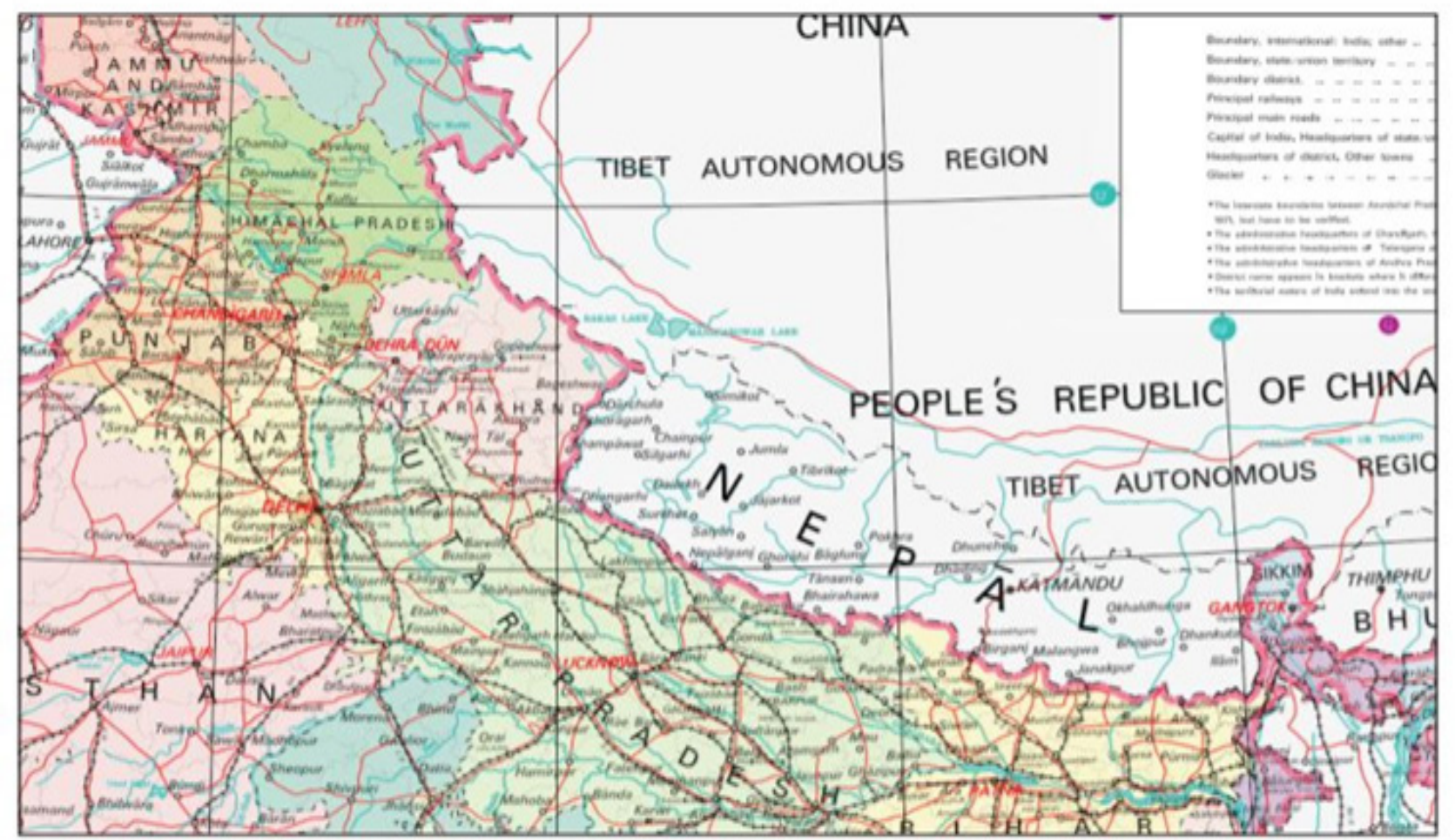

ource: Press Information Bureau, Government of India, 2 November 2019 https://pib.gov.in/PressReleseDetailm.aspx?PRID=1590112

Figure 2 Pithoragarh disctrict and Kalapani border. 


\section{History of this border}

Our story begins in the 1800 s, around 200 years ago, when India was under British rule. The British were trying to expand towards Nepal which was under a Kingdom the then kingdom of Gorkha. A battle took place between the British and the Kingdom of Nepal, which is called the Anglo Nepalese war of 1814. This battle Lasted for two years-until 1816-after which, a treaty was signed. This treaty was called of Sugauli, to decide which areas would be controlled by the British and the kingdom of Nepal. How much area would be assigned the countries at that time. According to the treaty of Sugauli, Nepal lost its area of Sikkim and Darjeeling. That area was ceded to the British and two rivers were used to define the kingdom of Nepal. The Western boundary of Nepal would be along the Mahakali River and the eastern boundary would be along the Mechi rever. Even today if we observe what the eastern and western boundaries of Nepal and India are then they are define according to these two rivers. The Nepal India border runs along the rivers. The problem arises at the western border of Nepal if go along the Mahakali River upstream, this river flows along. But the problem arises where the river splits into two. This river actually comes from two sources. Which sources should be chosen to define the border? If we take a closer look, one sources appears to be a proper river and second looks like a re rivulet. Common sense suggested that the wider stream of water should be used to define the borders as it is a proper river. ${ }^{11-15}$

So in this beginning, this is what the British did. The thicker part of the river, which lies on the west, was used to define the border. In the map drawn by the British, the west river was used to define the border and Nepal got this extra region (Figure 3). This map was drawn by the British in 1827 and the British choose the west river to define the boundary in this map. That is, this extra triangular part which the controversy is about-went to the Nepal kingdom. But some years later, the British realized that the extra piece of land that they had ceded to the Nepal kingdom. They needed it. This land held a lot of strategic importance because it would be useful while trading with China. So, some $30-40$ years later, in the 1860 s, the British changed their maps suddenly with a lot of cunning. Almost suddenly, they claimed the eastern river to be the boundary in their maps (Figure 4).

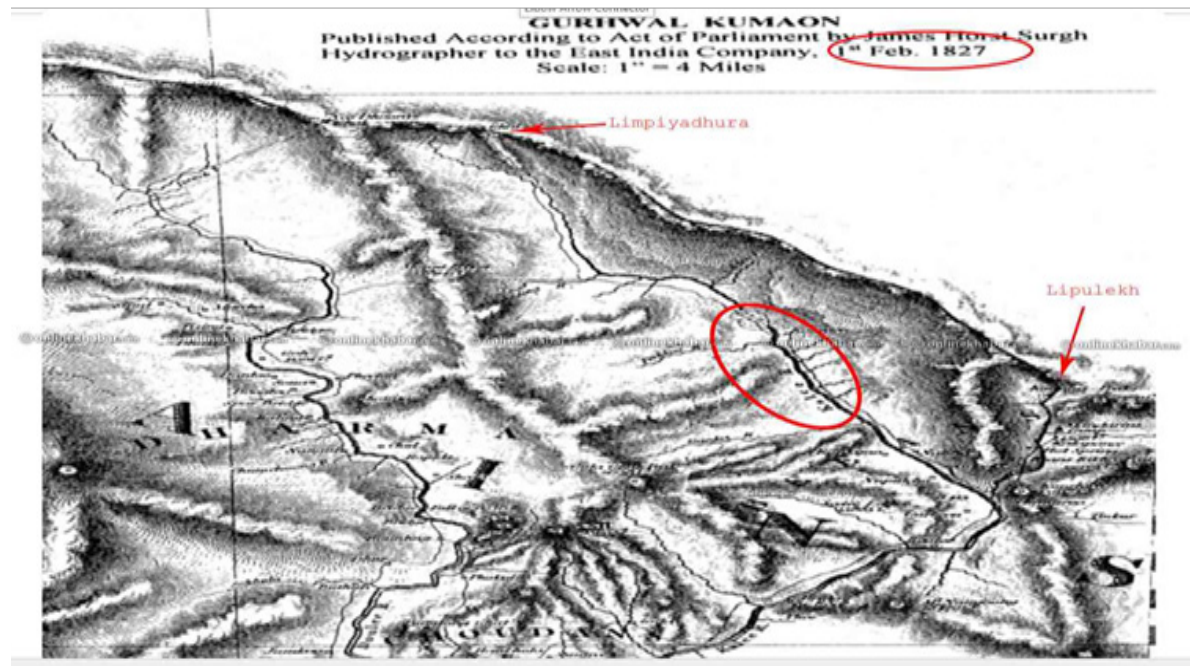

Figure 3 1827s British Map.

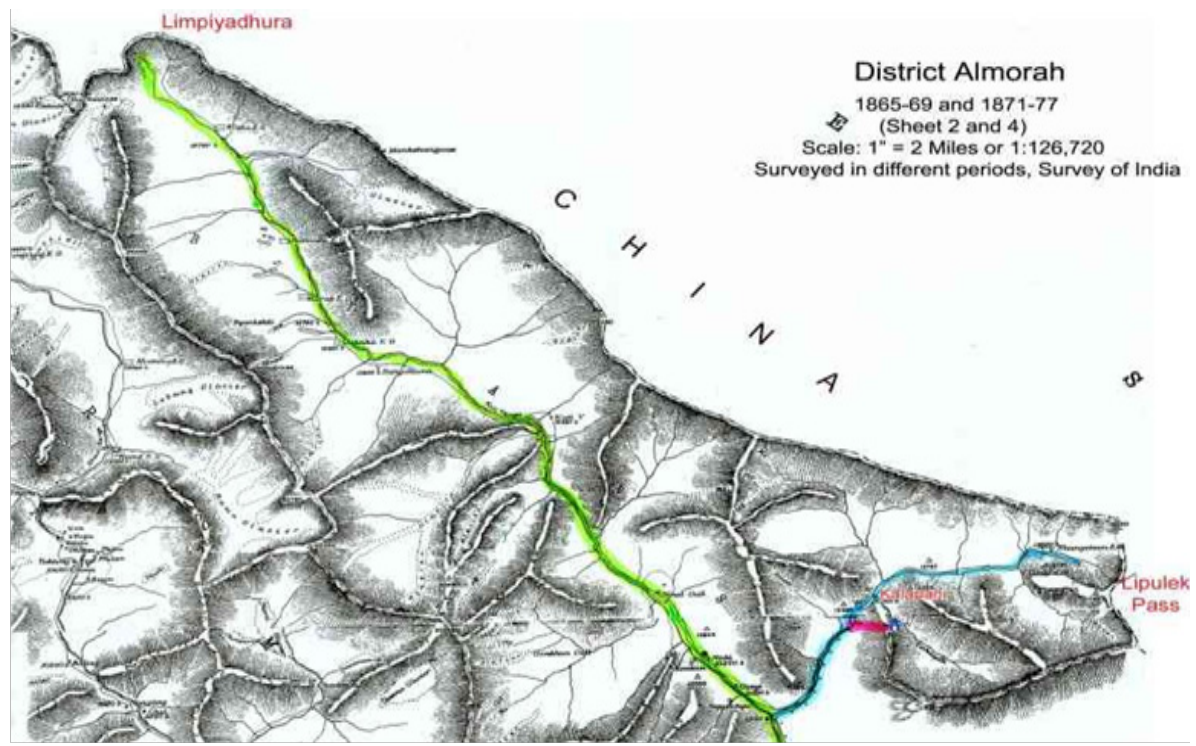

Figure 4 1867s Brithis Map. 
So, this map is $1865 \mathrm{~s}$. The eastern river was used by the British as a boundary between British India and the Kingdom of Nepal. The kingdom of Nepal did not have a problem with this at that time, because it was a small piece of land and it was not of much use from the perspective of Nepal. Almost no one live there, it was an extremely difficult terrain and only path crossed the boundary in their maps rough it- the pilgrimage route to reach Mansarovar. So, Nepal thought of letting it go as it did not make much of a difference. They let the British control it. This has been considered the Border ever since 1860 s to 1947 . And same border continue to be considered even after India became independent (Figure 5). ${ }^{16-20}$

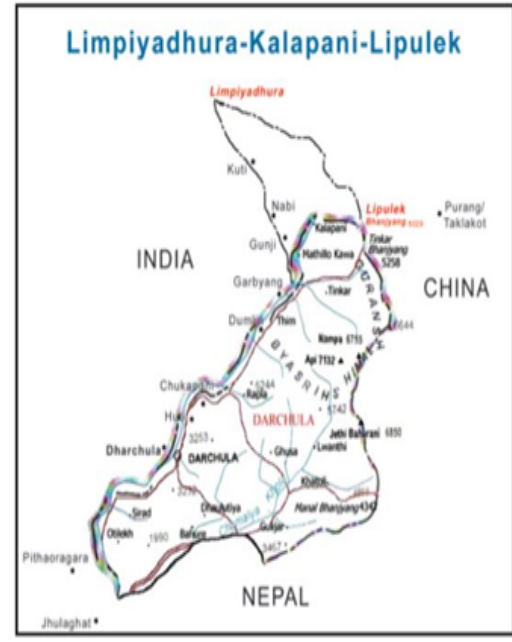

Source: Budddhi Narayan Shrestha, 'Authenticity of Lipulekh border pass', June 2015, https://bordernepal.wordpress.com/2015/06/29/authenticity-of-lipulek-border-pass/

Figure 5 Extra triangular part.

\section{Democracy in Nepal}

The Democracy came to Nepal pretty late. It became a democratic country in 1990. Before that, a monarchy was in power. So, even the monarchs of Nepal did not have an issue with this unofficial border. They kept this area out of Nepal while drawing their government maps. When tensions intensified between India and China in the 1960 s, which ultimately lead to an Indo-China war, then a military post was established by the Indian army in this area. Permission was sought from the Nepal monarchy, which again, did not have a problem with this. They gave permission for this for the protection of India. And ever since then, there is a presence of the Indian army in this area and there are established Indian military posts.

\section{After Indo-China war}

1962 onwards both India and Nepal have been showing Lipulekh and Kalapani in their respective maps. But is the first time that Nepal has shown the Limpiyadhura region in its map. The issue of this border dispute first reared its head in the 1990s when democracy came to Nepal. The democratic government was able to finally access the old historical papers to see how their monarchy defines their borders and then they realised that this area should belong to Nepal and ever since then they have been defining this as a disputed area. In July 2000, the former Indian Prime Minister Atal Bihari Vajpayee and then Nepali Prime Minister discussed upon this issue to solve the border dispute. They conducted a joint field survey to figure out where the exact boundary should be in the Kalapani region. But this agreement got clamped in the middle when India refused to withdraw its army presence from there. So discussion could not continue further. In May 2015 India and China signed a trade agreement to issue the Lipulekh pass as a trade route and this is the point when the India and Nepal relation began to sour. In 2015 the then Prime Minister of Nepal expressed this displeasure over the issues and showed objection. He claimed that the Kalapani region came under the ambit of Nepal. $\mathrm{He}$ protested in relation to this against both India and China (Figure 6). ${ }^{21-25}$

\section{Who is right? who does this territory belong to?}

So, the biggest question is who does this disputed area rightfully belong to India or Nepal? Nepal argues that the Sugauli treaty was the last treaty in which both sides were in agreement. After that there has been no Treaty in which both sides are in agreement. And so they would take the Sugauli as a base and on that basis, this area should be there because the treaty defines that their western boundary would be along the Mahakali river and where this river is divided into two, it is clearly visible that the wider river is the Mahakali river and so this area comes under them. The argument in India's favours it that Nepal said nothing regarding this for so many years. This border has been in use for decades. After the 1860s, this has been the unofficial boundary in use for centuries. Nepal did not object then. Neither did the monarch of Nepal have a problem with that. So what is the logic behind raising this issue suddenly and raising a dispute for nothing? In counter to this, Nepal could argue that democracy came to Nepal in the 1990s. Prior to that, the monarch ruled and exercised this own will. The people's will was never paid head to. Now that they have democracy, why should they obey the monarch if he agreed to an unofficial boundary?

Here, another argument in India's fever would be that even after 1990s, when Nepal had become democratic, Nepal had not declared the Limpiyadhura under it for so many years. So what changed so suddenly that it called for a new political map? 


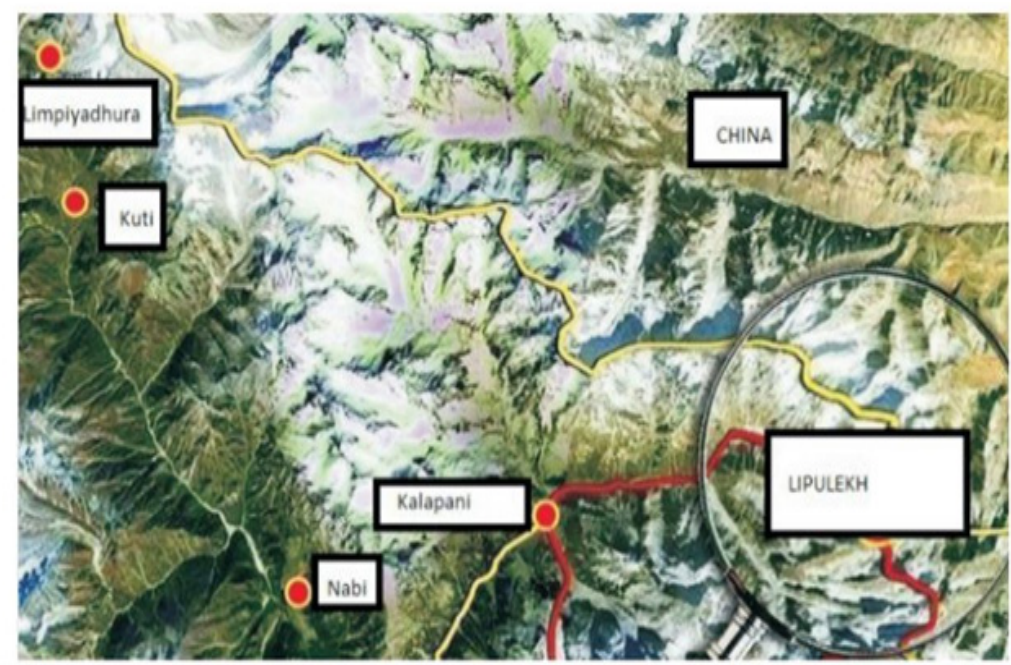

Source: https://www.change.org/p/kalapani-belong-to-nepal-situate-as-part-of-vyasa-valley-of-darchula-district-of-western-mahakali-not-of-india

Figure 6 Lipulekh Pass along with Kalapani.

If viewed geographically, then Nepal is correct in this situation. If we go according to the Sugauli treaty, which states that the western boundary of Nepal would be defined according to the MahaKali River. So it is quite clear that where the river is divided into two, the Western river is the bigger one and that should be used as a boundary. And according to this logic Nepal is right. But this situation is viewed practically and historically, and then India is right. This region should belong to India because the British to have been using this as a boundary since 1860s and if the monarchs of Nepal did not have an issue with it and this unofficial border was in use since many years. So if suddenly Nepal begins to claim that they want the 100 year old border, then it does not make any sense. If every country begins to behave this, then things will not work out. Such as, a situation arises between Germany and France, where Germany claims a particular region under France to be its own because the region was under them during the times of their older kingdoms. Although, it was not under them for the past hundred years they now stake a claim over it. Things will not work out this way there so many such countries and borders across the world where thing were different earlier but something new has been set now. Thirdly if we think logically, then this controversy should not have arisen. The border between India and Nepal is for namesake. Indians and Nepal is can anyway cross the border without a visa or passport and can reside and worked there. The other thing that can be kept aside is, the Prime Minister Jawaharlal Nehru told Indian parliament after independence in 1950 "we desire above all a strong and progressive independent Nepal our chief need not only our need but also the world's need is peace and stability in Nepal at present" and prime minister Narendra Modi in 2014 told Nepal's constitution assembly "how can India be happy each Nepal is unhappy". Indian ministry of external affairs spokesperson, he further added India has extended all possible technical medical and humanitarian assistance to Nepal. We have supplied about 25 tonnes of medical age to Nepal including Paracetamol and Hydroxychloroquine medicines, test kits and other medical supplies"

So what would be so special about the disputed area? The Nepalis and the Indians can live and work there, even today if they wish to. Both the Nepalese and the Indians can use the road which has been constructed. So what is the controversy about, then? Only about representing it on their political maps? Even as, Nepali prime minister claims at an event on the occasion of the $206^{\text {th }}$ birth anniversary of Nepal poet Bhanubhakta Acharya, who translated Valmiki Ramayana in Nepali, as well as Ayodha was an area West of Birgunj, a town bordering Bihar. He also said that Loard Ram was Nepali. And in this circumstance, the Nepalese government has banned India's news channels in Nepal.

\section{Why has this border dispute become so politically charged in Nepal?}

The Indian road was not built overnight and the Nepal government was really aware and monitoring the situation in Kalapani over the preceding months and years. This issue had come up in November last year, when India announced its new political map after the revocation of article 370. Actually Nepal government was facing its worst internal crisis since coming to power in 2017. Nepalese government was swiftly able to mobilize public opinion, play up nationalist sentiments against India, get his internal party rivals on board and divert attention from his failed ordinance and challenges to contain the pandemic. At the same time, several reports suggest that China has been paying NGOs in Nepal to write negatively about India Nepal relations. If we look at history, we will see that Nepal has sometimes gone to China or India for its own sake. However, at present, Nepal is much more inclined towards China. The reason can be said in 2019 president Xi Jinping has wrapped up a landmark visit to Nepal, the first by a Chinese President in 23 years, with 20 deals signed and nearly $\$ 500$ million in financial aid pledged amid Beijing's growing influence in the Himalayan nation and Xi Jinping also pledged to an upgrade the Arniko Highway linking Kathmandu with Tatopani transit point and China also used for Nepal greater cooperation in Belt and Road Initiative. A trans-Himalayan corridor is the offing. This will connect Lasa - the Tibetan capital with Kathmandu the capital of Nepal. As well as an agreement was signed between the investment board of government of Nepal and Huaxin Cement Narayani private limited under which the Chinese firm pledged Rs 14.4 billion (USD 130 million) of FDI to generate 3000 metric tonnes of cement per day. Another Mou was signed to prepare a detailed facility study on Eastern Tarai Irrigation system in the Biring, Kamala and Kankai rivers. And the two countries agreed on establishing the highland Food Park for varieties of fruit and vegetables with an investment of over USD 46 
million. They also agreed for the development of 184 MW Nepal Kaligandaki George Hydropower Project which would be developed in BOOT (build, own, operate, transfer) model. Furthermore, an agreement was signed for the construction of 40.27 MW Siuri Nyadi Hydropower Plant Project in EPCF model. An agreement between Nepal Pashmina Industries Association and One Belt One Road international trade platform of mutual trade Investment Company was signed for the sale of Nepali Pashmina in China. Pashmina is a fine type of Kashmiri wool. Pashmina products are made only in Kashmir and more recently in Nepal where the industry has seen a surge in production. The purchase order from China would be between 200000 to 500000 pieces every year. All these plans will strengthen Nepal's economy considerably. And for all these reasons, Nepal supports China's One Belt One Road policy and makes various comments against India.

\section{Importance of this road}

India has been in effective possession of this territory for at least 60 years. The region is of strategic importance and the new road is now one of the quickest links between Delhi and the Tibetan plateau. In 2015, statement China also recognised India sovereignty by agreeing to expand trade through the Lipulekh pass and finally this is also an important route for thousands of pilgrims who check across the border with China every year to visit the sacred Mount Kailash.

\section{What should the Indian government have done?}

Indian government should have been friendlier with the Government of Nepal. Talks about the construction of the road could have been held with Nepal prior to construction it and that both countries would benefit for it that the road was being constructed for the pilgrims of the Mansarovar and that this place was also of strategic importance to them. So an agreement could be reached together. The Government of India should make it a priority to begin talks with Nepal and solve the border issue it should negotiate in new set of mutually satisfactory arrangements. There are so many bold possibility maybe there could be joined deployment of military and police force during the 1960s on the Nepal China border. Given the trade potential both countries could also consider establishing a special economic zone. Finally it is in the interest of both that Indian and Nepali pilgrims can use the improved infrastructure in the Kalapani region to reach Mount Kailash. Rather than objects to Kathmandu's China ties, Delhi must focus on how to advance India's relations with Nepal. It should bet that the logic of Nepal's economic geography, it is pursuit of enlightenment selfinterest and Kathmandu's natural balancing politics will continue to provide a strong framework for India's future engagement with Nepal. Actually India had conducted a similar exercise with Bhutan to replace the 1949 treaty during 2006-2007 by a new set of mutually satisfactory arrangements. ${ }^{25-30}$

\section{Conclusion}

What is happening today is that Indians are making fun of Nepalese on social media and abusing them and Nepalis are writing hate comments against Indians. Some Indian politician are saying that this Nepalese have been sold off to China. The prime minister of Nepal said that the Indian virus was deadlier than the coronavirus. This friendship cannot be maintained among both the countries in this manner. And a friendship is essential because Indians and Nepal are so integrated with one another. Some Indians say that the Chinese have bought over the Nepalese because the ruling party in Nepal at present is a communist party and since there is also a ruling communist party in China, it is being said that a Chinese influence each being exerted on Nepal. It might be true some extent in the rest of the issues-the ongoing border dispute. But China has nothing to do with this and what are the reasons behind this? First of all, when there was a trade agreement between India and China in 2015 regarding the Lipulekh region then Nepal had protested against both the countries. And India and China why are forming relations with one another while Nepal was against both of them. Second reason is that the opposition party in Nepal holds the same opinion regarding this issue that the ruling party adheres to. Almost all the parties there are united over this issue that they believed this area to be theirs. In the end I would only like to say that I hope that these two countries solve this issue through discussions. This is very important because the connection or relation between India and Nepal is very strong and deep. Several Nepalese work in India and under the Indian government as well as in the army. Both sides would have to remain sensitive while solving this issue and would have to understand one another and understand each other's perspectives so that a solution can be worked out. ${ }^{31-33}$

\section{Acknowledgments}

None.

\section{Funding}

None.

\section{Conflicts of interest}

Author declares that there is no conflict of interest.

\section{References}

1. Naidu, Sushil K. Nepal-India Open Border's Security and Challenges. New Delhi: Gourav Book Centre pvt Ltd; 2016. p. 34.

2. Baral Raj Lok. Politics of Geo-politics: Continuity and Chang in IndiaNepal relations. New Delhi: Adarsh Books; 2018. p. 56.

3. Kumari Krishna. India Nepal relations: Then and Now. New Delhi: Prashant Publication; 2019. p. 87.

4. Baral Raj Lok, Pyakurel, Uddhab K. Nepal -India Open Borders: Problems and Prospects. New Delhi: Vij Books India Pvt Ltd; 2015. p. 45.

5. Shrestha, Buddhi N. Border Management of Nepal. Nepal, Kathmandu: Bhumichitra Co. P. Ltd; 2003. p. 126.

6. Bhatt SC. The triangle: India, Nepal, China-A study in treaty Relations New delhi: Gyan Publishing House; 2012. p.112.

7. Sing MK. India and Nepal Current Scenaro-(With Special Reference to Their Relations). New Delhi: Prasant Publication House; 2016. p.89.

8. BC Upreti. India-Nepal:Dynamics,issues and Problems. South Asian Survey, Sage Publication. 2003. P. 257-274.

9. Rajeev Kumar. India-Nepal border: Springboard for Opportunities', International Studies, No.50 (1 \& 2), Jawaharlal Nehru University: Sage Publications; 2016. p. 167.

10. Lok Raj Baral, Uddab P. Pyakurel, Op.cit, p. 45-46.

11. Andrea Blair Hernandez Forester. Non state Actors And The Open Border Policy: The Border Security Case Study of Nepal And India. Monterey, California: Naval Postgraduate School; 2014. p. 12.

12. Herald Bauder. Perspectives of Open Border and No Border. Geography Compass. 2015;9(7).

13. Subhakanta Behera. Trans-Border Identities (A study on the impact of Bangladeshi and Nepali migration to India). ICRIER Policy Series. 2011. 
14. Carens Joseph H. Aliens and Citizens: The Case for Open Borders. The Review of Politics. Cambridge University Press, for the University of Notre Dame du lac on behalf of Review of Politica. 1987;49(2):251-273.

15. Bansh Jha Hari. Addressing the Kalapani Issue between Nepal and India',2019, Expert Speak, Observer Research Foundation

16. Ranjan Amit. India-Nepal Row over the Updated Map of India. ISAS Working Paper. No. 321, Institute of South Asian Studies, National University of Singapore. 2019.

17. Vidya Bir Singh Kansakar. Nepal-India Open Border: Prospects, Problems and Challenges. Kathmandu: Tribhuvan University; p. 6.

18. Nepal-India Relations, Ministry of Foreign Affairs, Government of Nepal, Singha Durbar, Kathmandu, Nepal.

19. Baral Toya Nath. Border Disputes and Its Impact on Bilateral Relation: A Case of Nepal India International Border Management.

20. Shrestha Buddhi N. Nepal-China Border of Demarcation: Token of Friendship. 2007.

21. Shrestha Buddhi N. The Natural environments and the Shifting Borders of Nepal. 2014.

22. Baral Bhim N. Nepal-China -India: Prospects and Challenges of Trilateralism',2020, ResearchArticle, Department of Political Science, Tribhuvan University, Pokhara, Nepal, p. 16.
23. Chaudhury Aditya. New link road Kailash Mansarovar will cut down travel time 80 percent. 2020.

24. Cahudury, Dipanjan Roy, 'Road along Nepal border falls within Indian Territory. 2020.

25. Pradhan, Shirish B. Nepal protests to India over road passing through Lipulekh pass. 2020.

26. Government unveils new political map including Kalapani Lipulekh and Limpiyadhura inside Nepal border. 2020.

27. Diwanji Amberish K, 'India Nepal find common ground on noncontroversial issues. 2020.

28. Geeta Mohan, 'Kalapani an integral part: Nepal objects inclusion of unresolved territory as part of India in new maps. 2020.

29. Nepal objects to India China trade pact via Lipulekh pass. 2020.

30. Sukla Manish. China saved Nepal PM Oli's govt,he raised border dispute with india to repay favour. 2020.

31. Faizan Mustafa, 'On dilution, bifurcation and special status. 2020.

32. India has encroached upon two percent Nepali territory, says government spokesperson. 2019.

33. Pradeep Menyangbo. Nepal and India join hands to start a drive to clear no-man's land in Sunsari and Morang. The Kathmandu Post, 2019. 